Article

\title{
Reactivity of Metakaolin in Alkaline Environment: Correlation of Results from Dissolution Experiments with XRD Quantifications
}

\author{
Sebastian Scherb ${ }^{1, *(\mathbb{D})}$, Mathias Köberl ${ }^{1}$, Nancy Beuntner ${ }^{1}$, Karl-Christian Thienel ${ }^{1}$ (D) and \\ Jürgen Neubauer ${ }^{2}$ \\ 1 Civil Engineering and Environmental Science, Universität der Bundeswehr München, \\ Werner-Heisenberg-Weg 39, 85579 Neubiberg, Germany; mathias.koeberl@unibw.de (M.K.); \\ nancy.beuntner@unibw.de (N.B.); christian.thienel@unibw.de (K.-C.T.) \\ 2 GeoZentrum Nordbayern, Mineralogy, Friedrich-Alexander Universitaet Erlangen-Nuernberg, \\ Schlossgarten 5a, 91054 Erlangen, Germany; juergen.neubauer@fau.de \\ * Correspondence: sebastian.scherb@unibw.de
}

Received: 15 April 2020; Accepted: 11 May 2020; Published: 12 May 2020

\begin{abstract}
Systematic investigation of filtrates and filter residues resulting from a $24 \mathrm{~h}$ treatment of metakaolin in different alkaline solutions were performed. On filtered metakaolin particles, inductively coupled plasma-optical emission spectrometry (ICP-OES) measurements reveal an enrichment of iron and titanium, which suggests an inhomogeneous distribution of these cations. Since the $\mathrm{SiO}_{2} / \mathrm{Al}_{2} \mathrm{O}_{3}$ ratio remains constant in all filter residues examined, the dissolution of the $\mathrm{Si}$ and $\mathrm{Al}$ monomers is congruent. Structural differences, identified by attenuated total reflection-Fourier transform infrared spectroscopy (ATR-FTIR) as a consequence of alkali uptake, influence the X-ray scattering contribution of metakaolin, and thus quantifications with the partial or no known crystal structure (PONKCS) method. This leads to deviations between the degree of reaction calculated from $\mathrm{Si}$ and $\mathrm{Al}$ solubility from filtrate and that quantified by quantitative powder X-ray diffraction (QPXRD) using the filter residue. Nevertheless, the described changes do not cause a shift in the $X$-ray amorphous hump in case of congruent dissolution, and thus allow the quantification of the metakaolin before and after dissolution with the same hkl-phase model.
\end{abstract}

Keywords: metakaolin; degree of reaction; PONKCS; calcined clay; supplementary cementitious material; alkaline solution

\section{Introduction}

In recent years, the pozzolanic reactivity of calcined clays has increasingly moved into the focus of research. Their use as a supplementary cementitious material (SCM) could be a component to achieve the goal of more ecological concretes, since the replacement of cement by SCM offers one of the greatest opportunities to reduce $\mathrm{CO}_{2}$ emission in the production of concrete. The assessment of pozzolanic reactivity plays a crucial role in determining the possible degree of replacing cement with SCM and is directly linked to concrete strength and durability properties [1-6]. Different SCMs intervene variably in cement hydration by means of physical and chemical parameters and mechanisms $[7,8]$. Various scientists were investigating the question of a test method suitable for assessing the pozzolanic reactivity of different SCM directly from the respective SCM [9-18]. Another approach is the determination of the reaction degree of SCM in cementitious systems [19-30]. Different parameters such as the reactive silica content, the $\mathrm{CaO}$ or $\mathrm{Ca}(\mathrm{OH})_{2}$ consumption, the relative strength index or the content of soluble silicon ( $\mathrm{Si}$ ) and aluminum (Al) ions in alkaline solution are common to assess the pozzolanic reactivity. Different wet chemical, analytical and empirical methods such 
as thermogravimetric analysis, isothermal calorimetry, quantitative X-ray diffraction (QXRD) or compressive strength are used for the different approaches.

For calcined clays, which, in addition to silicon, can provide a considerable amount of reactive aluminum, comparison of the test methods revealed a considerable variation in the suitability of individual methods, even if they work very well in some other cases, e.g., for fly ash or slag [13,23,31-34].

The quantification of X-ray amorphous SCM with the partial or no known crystal structure (PONKCS) method [35] is a powerful tool to determine the SCM content in blended cements [36,37]. Quantification of SCM in hydrating systems is a challenging task due to strong overlap of the broad SCM peaks with X-ray amorphous hydrates and the free, not chemically bound, water [36,38]. The latest research confirms the possibility of quantifying the reacted SCM during in situ XRD measurements of hydrating systems [28]. Others show that the calculation of the degree of reaction can lead to major deviations resulting from error propagation. This depends largely on the substitution rate of the SCM and the degree of reaction $[23,26,36]$.

Due to the high temperatures $\left(1100-1700{ }^{\circ} \mathrm{C}\right)$ and fast cooling involved in the formation of fly ash, a large proportion of the particles are vitreous. The calcination of clays takes place at significantly lower temperatures $\left(600-900^{\circ} \mathrm{C}\right)$. Even if crystalline clay minerals are transformed into X-ray amorphous "metaphases", their habitus and layer structure remain intact (pseudomorphosis). According to Brindley and Nakahira [39], a pseudohexagonal skeleton of [ $\left.\mathrm{SiO}_{4}\right]$-tetrahedra in the metakaolin is preserved at calcination temperatures of $600{ }^{\circ} \mathrm{C}$. Massiot et al. [40] describe effects observed with nuclear magnetic resonance (NMR) between 450 and $850^{\circ} \mathrm{C}$ as a newly formed silicon network without structural long-range order. In contrast to fly ash, in which the silicon release takes place via a solution process of the vitreous particles in alkaline environment [41], the mechanism of ion release of calcined clays is not finally investigated. Granizo et al. [42] describe the leaching kinetics of metakaolin in 5 and $8 \mathrm{M} \mathrm{NaOH}$ solution as a three-stage process. According to their hypothesis, the dissolution process is initially incongruent for a short time, followed by a longer period of congruent dissolution behavior and, finally, incongruent again. Garg and Skibsted [43] show that crystallographic defects accelerate dissolution in alkaline solution during the first hours, followed by a period where the rate of reaction is constant. They conclude that the dissolution process of metakaolin calcined at $500{ }^{\circ} \mathrm{C}$ is congruent and becomes increasingly incongruent with increasing calcination temperature. An incongruent dissolution process of metakaolin could lead to changes in the contribution of metakaolin to the diffractogram and thus falsify the quantifications with the PONKCS method. This is the starting point of this study, which intends to provide an insight into the following questions: Is there a correlation between the amount of Si- and Al-ions in alkaline solution derived from dissolution tests and the quantification of the metakaolin with the PONKCS method? How does the dissolution process of metakaolin affect its X-ray amorphous hump in the diffractogram? Although the reactivity of metakaolin has been described in numerous publications $[14,15,17,27]$ and its content has already been quantified $[26,28,36]$, the previous questions raised have not yet been considered. Therefore, the method of Kaps and Buchwald [11,12] is used to determine the pozzolanic reactivity of metakaolin on the basis of the solubility of Si- and Al-monomers in alkaline solution. A systematic investigation of the filter residue should provide information about the processes taking place during ion release, the impact on the metakaolin and correlations between the ions dissolved and the quantity evaluated with the PONKCS method for the first time. The contribution of this work shows the possibilities and limitations of the established methods. A better understanding contributes directly to improving the quantification with the PONKCS method and the assessment of the results obtained. Thus, the present study contributes to the evaluation of the suitability of calcined clays as SCM. 


\section{Materials and Methods}

\subsection{Materials and Test Program}

The investigation deals with the solubility behavior of metakaolin (MK) in deionized water and various alkaline solutions. The flash calcined metakaolin is commercially available and was ready for use. The chemical composition was determined by inductively coupled plasma-optical emission spectrometry (ICP-OES) and the mineralogical composition by quantitative powder X-ray diffraction (QPXRD) with $20 \mathrm{wt} . \% \mathrm{ZnO}$ as an internal standard to determine the X-ray amorphous content (Table 1). The data have already been published by the authors in $[38,44]$.

Table 1. Chemical composition, loss on ignition (LOI) and mineralogical composition of metakaolin (MK) $[38,44]$.

\begin{tabular}{cccc}
\hline Oxides (wt.\%) & MK & Phases (wt.\%) & MK \\
\hline $\mathrm{SiO}_{2}$ & 54.5 & Quartz & 5.0 \\
$\mathrm{Al}_{2} \mathrm{O}_{3}$ & 40.2 & Anatase & 0.6 \\
$\mathrm{Fe}_{2} \mathrm{O}_{3}$ & 1.8 & Phengite & 1.4 \\
$\mathrm{CaO}$ & $<0.1$ & X-ray amorphous & 93.0 \\
$\mathrm{MgO}$ & 0.2 & & \\
$\mathrm{SO}_{3}$ & $<0.1$ & & \\
$\mathrm{Na}_{2} \mathrm{O}$ & 0.3 & & \\
$\mathrm{~K}_{2} \mathrm{O}$ & 0.3 & & \\
$\mathrm{TiO}_{2}$ & 1.4 & & \\
$\mathrm{LOI}$ & 1.3 & & \\
\hline
\end{tabular}

For the experiments, $5 \mathrm{~g}$ MK was shaken in $400 \mathrm{~mL}$ solution for $24 \mathrm{~h}$ on a vibrating unit. The solutions used were deionized water $\left(\mathrm{H}_{2} \mathrm{O} ; \mathrm{pH}=5.8\right)$ as reference, $10 \mathrm{wt}$.\% sodium hydroxide solution $(\mathrm{NaOH} ; \mathrm{pH}=13,2), 10 \mathrm{wt}$ \% potassium hydroxide solution $(\mathrm{KOH} ; \mathrm{pH}=14.1)$ and a model pore solution of $100 \mathrm{mmol} / \mathrm{L} \mathrm{NaOH}$ and $500 \mathrm{mmol} / \mathrm{L} \mathrm{KOH}(\mathrm{MOH} ; \mathrm{pH}=13.5)$. The $\mathrm{pH}$ of the suspensions was measured after $5 \mathrm{~min}, 30 \mathrm{~min}, 6 \mathrm{~h}$, and $24 \mathrm{~h}$. The measurements of the $\mathrm{pH}$ were carried out with the digital pH meter WTWmulti 3430 with SenTix 940-3 pH-electrode (WTW, Weilheim, Germany). Two independent preparations were applied for each solution. Subsequently, the samples were filtered through a suction filter with depression. Both the filtrate and the filter residue were used for further analysis. The filter residue was first kept in the filter and washed with distilled water until the measured $\mathrm{pH}$ value of the water leaking from the filter was less than 8 . This procedure was necessary to prevent the hydroxide solutions from adhering to the particle surfaces and falsifying further analyses of the filter residue. Finally, the filter residue was dried over night at $60{ }^{\circ} \mathrm{C}$ in a warming cabinet and carefully crushed in an agate hand mortar the next day. The differences between drying a sample without prior washing and drying a washed sample are shown in Figure 1. Analogous to other studies [45,46], the carbonization of $\mathrm{NaOH}$ can be clearly identified.

In addition to weighing the filter residue, following methods were used to analyze the sample:

1. Quantitative Powder X-Ray Diffraction (QPXRD);

2. Scanning Electron Microscopy/Energy Dispersive X-ray analysis (SEM/EDX);

3. Element analysis by Inductively Coupled Plasma Optical Emission Spectrometry (ICP-OES);

4. Attenuated Total Reflection-Fourier Transform Infrared spectroscopy (ATR-FTIR).

The filtrate was acidified with concentrated $\mathrm{HCl}$ to a $\mathrm{pH}$ of 1 and filled up to $500 \mathrm{~mL}$ in a volumetric flask with distilled water, ready for ICP-OES analysis. A schematic summary of the experimental program is shown in Figure 2. 


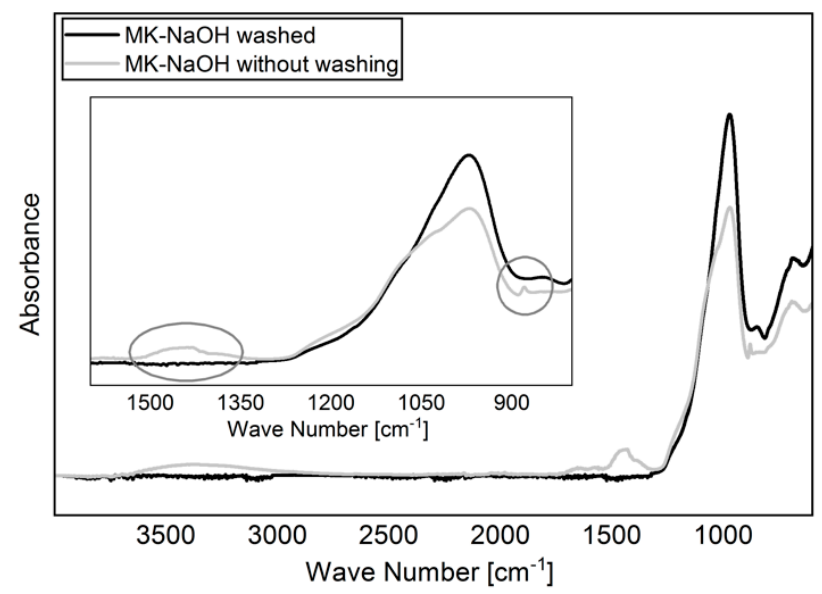

Figure 1. FTIR spectra of dried MK-NaOH after and without prior washing the sample. The carbonization of adhered $\mathrm{NaOH}$ to the particle surfaces can be avoided by washing the sample.

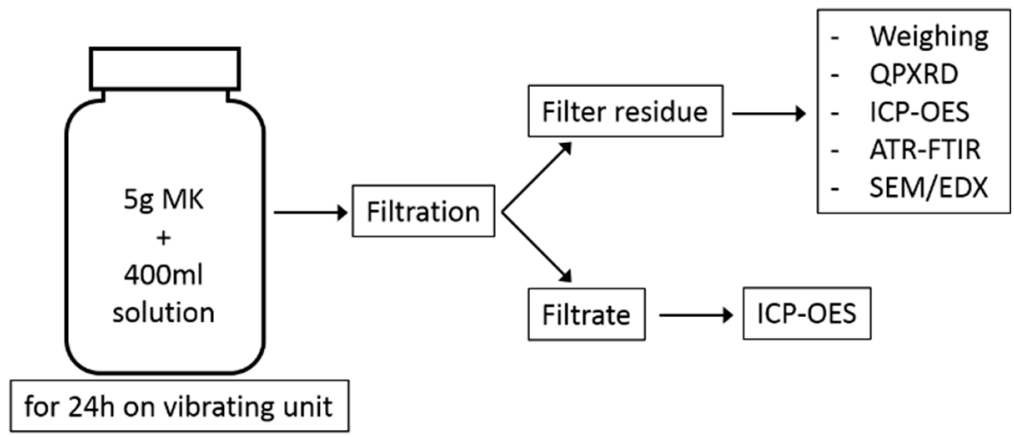

Figure 2. Schematic illustration of the test program.

\section{2. $Q P X R D$}

XRD measurements were performed with a PANalytical Empyrean diffractometer equipped with a primary Bragg-Brentano ${ }^{\mathrm{HD}}$ monochromator and a PIXcel ${ }^{1 \mathrm{D}}$ linear detector (Malvern Panalytical, Malvern, UK). A diffractogram was taken from $4^{\circ}$ to $42^{\circ} 2 \Theta$ in continuous scan mode with a step size of 0.013 and a counting time of $25.5 \mathrm{~s}$ per step at $40 \mathrm{kV}$ and $40 \mathrm{~mA}$ with $\mathrm{CuK} \alpha$ radiation. Measurements were analyzed with the software HighScore 4.7. The sample was prepared with a back-loading tool and covered with a Kapton film (DuPont, Wilmington, DE, USA). The use of the Kapton film allows to summarize the instrumental background and the background caused by the Kapton film and ensures a stable refinement [38]. The quantifications were performed combining external standard $[47,48]$ and PONKCS method [35,49]. Table 2 shows the structures used for Rietveld refinement of the crystalline components of the sample.

Table 2. Inorganic Crystal Structure Database (ICSD) structure data for the Rietveld refinement.

\begin{tabular}{ccc}
\hline Phase & Author & ICSD-No. \\
\hline Quartz & Le Page and Donnay [50] & 174 \\
Anatase & Horn, et al. [51] & 9854 \\
Phengite & Ivaldi, et al. [52] & 158072 \\
\hline
\end{tabular}

The calibrations for quantitative analysis of the hkl-phases were performed with $\mathrm{ZnO}$ as internal standard. The procedure for creating the hkl-phases, their calibration, as well as the refinement parameters, are described in detail in [38]. 


\subsection{SEM/EDX}

For the SEM/EDX analyses, the dried samples were embedded in epoxy resin, ground and polished with isopropanol after hardening, and finally coated with carbon. Since the habitus of the particles is not easily recognizable on embedded samples, a second set of samples was prepared by scattering the powder on two-component adhesives, followed by coating with gold.

The analyses were performed on a Zeiss Evo LS 15 (Zeiss, Oberkochen, Germany) equipped with an Oxford X-Max 50 EDX detector (Oxford Instruments, High Wycombe, UK) at $20 \mathrm{kV}$ and a working distance of $8.5 \mathrm{~mm}$. The EDX analyses were measured against a kaolinite standard (Processing Plant, Bugle, Cornwall, UK from Micro-Analysis Consultants Ltd.) of known composition. Each EDX spectrum was collected for 100 live seconds of accumulated count duration. In the EDX analyses, special attention was paid to the metakaolin particles and areas were selected for analysis in which no crystalline phases could be detected on the surface. Thus, the EDX analyses represent the chemical composition of the $\mathrm{X}$-ray amorphous part of the sample $\left(\mathrm{MK}_{\mathrm{Am}}\right)$.

\subsection{ICP-OES}

The filter residue had to be solved for ICP-OES analysis in nitric acid after melt fusion using lithium metaborate. For this purpose, $0.4 \mathrm{~g}$ of the sample was weighed with $1.6 \mathrm{~g}$ lithium metaborate and melted at $950{ }^{\circ} \mathrm{C}$ in a platinum crucible in a muffle furnace. In the next step, the melted sample was quenched in $200 \mathrm{~mL}$ concentrated nitric acid $\left(65 \mathrm{wt} . \% \mathrm{HNO}_{3}\right)$ and dissolved in an ultrasonic bath. Finally, the solution was filled up to $500 \mathrm{~mL}$ in a volumetric flask with distilled water.

The ICP-OES measurements were performed with a Varian 720 ES spectrometer (Agilent Technologies, Santa Clara, CA, USA) and evaluated with the software 1.1 supplied with the instrument. The measuring range for the respective element was adapted using a multi-point calibration with an external standard. The measurements and their evaluation were conducted according to [53]. The chemical composition of the $\mathrm{X}$-ray amorphous content $\left(\mathrm{MK}_{\mathrm{Am}}\right)$ was calculated from the total analysis of the MK. The fractions of quartz $\left(\mathrm{SiO}_{2}\right)$ and anatase $\left(\mathrm{TiO}_{2}\right)$ determined by QPXRD were subtracted from the oxidic composition. For phengite, the individual oxidic components were calculated using an idealized phengite formula $\left(\mathrm{KAl}_{1.5} \mathrm{Fe}_{0.5}\left(\mathrm{Al}_{0.5} \mathrm{Si}_{3.5} \mathrm{O}_{10}\right)(\mathrm{OH})_{2}\right)$ and subtracted from the total analysis. Finally, the calculated oxides were normalized to $100 \%$. This method provides comparable results to the EDX analysis and was used to cross check the EDX measurements. The deviation of the ICP results from the EDX analyses is $\pm 1 \mathrm{wt} . \%$ for the main elements (>10 wt. $\%$ ) and $\pm 0.5 \mathrm{wt} . \%$ for the secondary elements $(<10 \mathrm{wt} . \%)$.

\subsection{ATR-FTIR}

The ATR-FTIR analyses were performed on a ThermoFisher Scientific Nicolet iS10 FTIR spectrometer equipped with an EverGlo TM MIR radiation source $\left(\lambda=15,798 \mathrm{~cm}^{-1}\right)$ and dTGS detector (Waltham, MA, USA). The spectra were measured in the wavenumber range from $400-4000 \mathrm{~cm}^{-1}$ with diamond as ATR crystal, collecting a series of 16 scans at a resolution of $4 \mathrm{~cm}^{-1}$. The evaluation of the data was carried out with Omnic 9.3 (ThermoFisher Scientific, Waltham, MA, USA).

\subsection{Calculation of the Degree of Reaction}

The degree of reaction was calculated with different approaches using the results from weighing the filter residue,

$$
\mathrm{R}_{\text {weight }}[\%]=\left[1-\frac{\mathrm{m}_{\text {filter }}-\mathrm{m}_{\text {cry }}}{\mathrm{m}_{\mathrm{MKAm}}}\right] \times 100
$$

the XRD quantification of the quartz,

$$
\mathrm{R}_{\text {Quartz }}[\%]=\left[1-\frac{\mathrm{m}_{\text {Quartz }} \times \frac{100}{c_{\text {Quartz }}}-\mathrm{m}_{\text {cry }}}{\mathrm{m}_{\text {MKAm }}}\right] \times 100
$$


the amorphous content $\left(\mathrm{MK}_{\mathrm{Am}}\right)$ and

$$
\mathrm{R}_{\text {MKAm }}[\%]=\left[1-\frac{\mathrm{m}_{\text {cry }} \times \frac{100}{\left(100-c_{\text {MKAm }}\right)}-m_{\text {cry }}}{m_{\text {MKAm }}}\right] \times 100
$$

from Si- and Al-solubility $\left(\mathrm{R}_{\mathrm{Si} / \mathrm{Al}}[\%]\right)$.

The calculation of the degree of reaction from weighing the filter residue $\left(\mathrm{m}_{\text {filter }}[\mathrm{g}]\right)$ (Equation (1)) is based on the assumption that the absolute amount of crystalline phases of the sample remains constant and does not dissolve during shaking. The mineralogical composition was used to calculate the absolute mass of the crystalline phases $\left(\mathrm{m}_{\text {cry }}=0.35 \mathrm{~g}\right)$ and the weight of the $\mathrm{MK}_{\mathrm{Am}}\left(\mathrm{m}_{\mathrm{MKAm}}=4.65 \mathrm{~g}\right)$ in $5 \mathrm{~g}$ of the sample.

The calculations from the QPXRD results are also based on the assumption that the crystalline phases do not dissolve during the experiment. For the calculation of the reaction degree from the quartz content (Equation (2)), the absolute mass of quartz $\left(\mathrm{m}_{\mathrm{Quartz}}=0.25 \mathrm{~g}\right)$ in $5 \mathrm{~g}$ sample was used. The degree of reaction can be calculated directly from its quantification ( $\left.c_{Q u a r t z}\right)$. For the calculation of the degree of reaction from the quantification of $\mathrm{MK}_{\mathrm{Am}}\left(\mathrm{c}_{\mathrm{MKAm}}\right)$ (Equation (3)), the total crystalline content of the sample (100 - $\left.\mathrm{C}_{\text {MKAm }}\right)$ was taken into account.

The degree of reaction from the ion solubility $\left(\mathrm{R}_{\mathrm{Si} / \mathrm{Al}}\right)$ is calculated from the quotient of the sum of the dissolved $\mathrm{Si}$ - and $\mathrm{Al}$-ions and the initial content of $\mathrm{Si}$ and $\mathrm{Al}$ in $\mathrm{MK}_{\mathrm{Am}}$. The chemical composition of the ICP-OES analysis was used to calculate the initial content of $\mathrm{Si}$ and $\mathrm{Al}$ in $\mathrm{MK}_{\mathrm{AM}}(2.3 \mathrm{~g})$.

\section{Results}

\subsection{Time Dependent $p H$ Values of the Suspensions}

Table 3 shows the time-dependent $\mathrm{pH}$-values of the suspension. There are almost no measurable changes during the observation period. Previous investigations show that the measurement of $\mathrm{pH}$ values at very high concentrations with a glass electrode is faulty and is underdetermined due to the alkali error [54]. This effect occurs mainly with $\mathrm{NaOH}$. Due to the logarithmic nature of the $\mathrm{pH}$ scale, even significant changes in concentration at very high concentrations cause only a slight change in the $\mathrm{pH}$ value. Accordingly, no conclusions can be drawn at this point from the results of the $\mathrm{pH}$ measurements at such high concentrations of $\mathrm{KOH}$ and $\mathrm{NaOH}$.

Table 3. Time dependent $\mathrm{pH}$-values of the different MK suspensions.

\begin{tabular}{|c|c|c|c|c|}
\hline & $\mathrm{MK}-\mathrm{H}_{2} \mathrm{O}$ & MK-MOH & МК-КОН & $\mathrm{MK}-\mathrm{NaOH}$ \\
\hline $\mathrm{pH}$ after $5 \mathrm{~min}$ & 5.8 & 13.5 & 14.1 & 13.1 \\
\hline $\mathrm{pH}$ after $30 \mathrm{~min}$ & 6.0 & 13.5 & 14.0 & 13.0 \\
\hline $\mathrm{pH}$ after $6 \mathrm{~h}$ & 6.0 & 13.4 & 14.0 & 12.9 \\
\hline $\mathrm{pH}$ after $24 \mathrm{~h}$ & 6.2 & 13.5 & 14.1 & 13.1 \\
\hline
\end{tabular}

\subsection{Weighing the Filter Residue}

Table 4 lists the masses of the filter residues determined after $24 \mathrm{~h}$ of dissolution, filtration, washing and drying. The given error was determined from the deviation of the mean value of the two individual determinations. As expected, the difference to the initial weight $(5 \mathrm{~g})$ is small for MK stored in distilled water. In contrast, the weight loss with the various alkaline solutions is very clear, with $\mathrm{MK}-\mathrm{NaOH}$ showing by far the highest one, with approximately $3 \mathrm{~g}$. A conventional presentation of the results in wt.\% falsifies the results due to the presence of crystalline phases in the sample, which might not dissolve. 
Table 4. Results of weighing the filter residue after dissolution of $5 \mathrm{~g} \mathrm{MK}$ in different solutions in $\mathrm{g}$.

\begin{tabular}{cccc}
\hline $\mathrm{MK}^{-\mathrm{H}_{2} \mathrm{O}}$ & MK-MOH & MK-KOH & MK-NaOH \\
\hline $4.93 \pm 0.05$ & $4.27 \pm 0.10$ & $3.75 \pm 0.10$ & $2.04 \pm 0.20$ \\
\hline
\end{tabular}

\section{3. $Q P X R D$}

Figure 3 shows the diffractograms of the filter residues. For the sake of a clearer overview, the MK-MOH measurement is not given. The intensity is expressed as a square root of the counts and the peaks of the crystalline phases are partially cut off. This emphasizes the changes in the $\mathrm{X}$-ray amorphous hump. The diffractograms $\mathrm{MK}$ and $\mathrm{MK}-\mathrm{H}_{2} \mathrm{O}$ are almost congruent. Thus, no structural change can be detected when the sample (MK) is treated with distilled water $\left(\mathrm{MK}-\mathrm{H}_{2} \mathrm{O}\right)$. With MK-KOH, a slight decrease in the $\mathrm{X}$-ray amorphous hump and a slightly higher maximum intensity of the peaks in the crystalline phases can be observed. This trend becomes more pronounced with $\mathrm{MK}-\mathrm{NaOH}$ and leads to clearly discernible differences between $\mathrm{MK}$ and $\mathrm{MK}-\mathrm{NaOH}$. The increase in the intensity of the peaks of the crystalline phases is clearly visible at the (011)-reflex of the quartz, which is highlighted in the enlarged insert displaying a range from $26-27^{\circ} 2 \Theta$ (Figure 3 ).

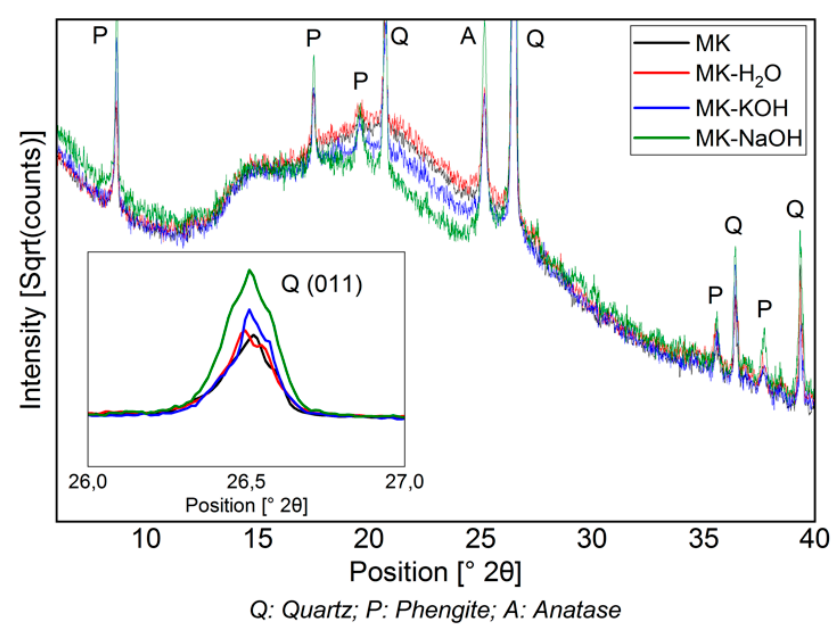

Figure 3. Diffractogram $(\mathrm{CuK} \alpha)$ of $\mathrm{MK}$ compared to those of insoluble residues of MK treated with different solutions. The decrease in the X-ray amorphous hump and the enrichment of crystalline phases (quartz peak (011) is highlighted in the enlarged range between $26-27^{\circ} 2 \Theta$ ) can be seen.

Table 5 summarizes the results of the XRD quantifications. An enrichment of all crystalline phases and a decrease in $\mathrm{MK}_{\mathrm{Am}}$ from $\mathrm{MK}-\mathrm{MOH}$ via $\mathrm{MK}-\mathrm{KOH}$ to $\mathrm{MK}-\mathrm{NaOH}$ can be observed.

Table 5. Results of QPXRD in $w t \%$. The absolute error is $\pm 0.5 \mathrm{wt} . \%$ for the crystalline phases and \pm 1 wt. $\%$ for $\mathrm{MK}_{\mathrm{AM}}$.

\begin{tabular}{cccccc}
\hline Phase & MK & MK-H $\mathbf{2}_{\mathbf{2}} \mathbf{O}$ & MK-MOH & MK-KOH & MK-NaOH \\
\hline Quartz & 5.0 & 5.2 & 5.6 & 6.3 & 12.0 \\
Anatase & 0.6 & 0.6 & 0.6 & 0.8 & 1.1 \\
Phengite & 1.4 & 1.5 & 1.7 & 2.1 & 3.1 \\
MK $_{\text {Am }}$ & 93.0 & 92.8 & 92.1 & 90.8 & 83.4 \\
\hline
\end{tabular}

\subsection{Chemical Analysis}

Table 6 shows the ion content of main elements in the filtrates obtained after the reaction of different solutions with MK. Distilled water treatment $\left(\mathrm{MK}-\mathrm{H}_{2} \mathrm{O}\right)$ results in a low ion content for Si and Al. Here, the values for Fe and Ti are below the detection limit. The dissolved ion content increases 
with increasing alkali metal ion content of the alkaline solutions. It is noticeable that the content of Fe and Ti remains very low and changes only slightly with increasing $\mathrm{pH}$, while Si- and Al-ion contents rise drastically.

Table 6. Ion content [mg] of the filtrate measured with ICP-OES (after the experiment of $5 \mathrm{~g}$ sample in 400 mL solution).

\begin{tabular}{ccccc}
\hline Elements & MK- $\mathbf{H}_{\mathbf{2}} \mathbf{O}$ & MK-MOH & MK-KOH & MK-NaOH \\
\hline $\mathrm{Si}$ & 24 & 211 & 353 & 866 \\
$\mathrm{Al}$ & 19 & 191 & 341 & 828 \\
$\mathrm{Fe}$ & $-{ }^{*}$ & 7 & 9 & 15 \\
$\mathrm{Ti}$ & $-{ }^{*}$ & 3 & 5 & 8 \\
\hline \multicolumn{5}{c}{ * Detection limit is $0.5 \mathrm{mg}}$.
\end{tabular}

Table 7 gives the results of the ICP-OES analyses of the filter residues. Since the values from the EDX analyses (Section 2.3) show only a small deviation from the ICP-OES results after correction of the crystalline phase content (Section 2.4), they are not shown additionally in the main text. The EDX results are available as supplementary Table S1. Overall, it can be stated that both the $\mathrm{SiO}_{2}$ and the $\mathrm{Al}_{2} \mathrm{O}_{3}$ content of $\mathrm{MK}_{\mathrm{Am}}$ and $\mathrm{MK}_{\mathrm{Am}-\mathrm{H} 2 \mathrm{O}}$ decreases via $\mathrm{MK}_{\mathrm{Am}-\mathrm{MOH}}, \mathrm{MK}_{\mathrm{Am}-\mathrm{KOH}}$ and $\mathrm{MK}_{\mathrm{Am}-\mathrm{NaOH}}$. The values for $\mathrm{MK}_{\mathrm{Am}-\mathrm{MOH}}$ and $\mathrm{MK}_{\mathrm{Am}-\mathrm{KOH}}$ are in a similar range, while $\mathrm{MK}_{\mathrm{Am}-\mathrm{NaOH}}$ shows a further and more pronounced decrease. This correlates with the increasing Si- and Al-ion solubility (Table 6). For $\mathrm{Fe}_{2} \mathrm{O}_{3}$ and $\mathrm{TiO}_{2}$, where hardly any ion solubility can be measured (Table 6), the trend is opposite and an enrichment takes place. Furthermore, an uptake of alkalis can be detected, corresponding to the alkalinity of the solution used.

Table 7. Chemical composition [wt.\%] of $\mathrm{MK}_{\mathrm{Am}}$ left after dissolution with different solvents of all samples measured with ICP-OES and the molar ratio of $\mathrm{SiO}_{2} / \mathrm{Al}_{2} \mathrm{O}_{3}$ and $\mathrm{SiO}_{2} /\left(\mathrm{Al}_{2} \mathrm{O}_{3}+\mathrm{Fe}_{2} \mathrm{O}_{3}+\mathrm{TiO}_{2}+\right.$ $\left.\mathrm{Na}_{2} \mathrm{O}+\mathrm{K}_{2} \mathrm{O}\right)$.

\begin{tabular}{cccccc}
\hline Oxides & $\mathbf{M K}_{\mathbf{A m}}$ & $\mathbf{M K}_{\text {Am-H2O }}$ & $\mathbf{M K}_{\text {Am-MOH }}$ & $\mathbf{M K}_{\text {Am-KOH }}$ & $\mathbf{M K}_{\text {Am-NaOH }}$ \\
\hline $\mathrm{SiO}_{2}$ & 53.2 & 52.8 & 51.4 & 51.2 & 49.5 \\
$\mathrm{Al}_{2} \mathrm{O}_{3}$ & 43.7 & 43.6 & 42.3 & 42.2 & 40.0 \\
$\mathrm{CaO}$ & 0.1 & 0.1 & 0.1 & 0.1 & 0.1 \\
$\mathrm{Fe}_{2} \mathrm{O}_{3}$ & 1.5 & 1.8 & 2.1 & 2.1 & 3.1 \\
$\mathrm{~K}_{2} \mathrm{O}$ & 0.0 & 0.0 & 2.0 & 2.7 & 0.0 \\
$\mathrm{MgO}$ & 0.2 & 0.3 & 0.2 & 0.1 & 0.2 \\
$\mathrm{Na}_{2} \mathrm{O}$ & 0.3 & 0.4 & 0.5 & 0.1 & 5.1 \\
$\mathrm{TiO}_{2}$ & 0.9 & 0.9 & 1.5 & 1.4 & 2.0 \\
\hline $\mathrm{SiO}_{2} / \mathrm{Al}_{2} \mathrm{O}_{3}$ & 2.07 & 2.05 & 2.06 & 2.06 & 2.10 \\
$*$ & 1.95 & 1.92 & 1.80 & 1.79 & 1.59 \\
\hline \multicolumn{7}{c}{$* \mathrm{SiO}_{2} /\left(\mathrm{Al}_{2} \mathrm{O}_{3}+\mathrm{Fe}_{2} \mathrm{O}_{3}+\mathrm{TiO}_{2}+\mathrm{Na}_{2} \mathrm{O}+\mathrm{K}_{2} \mathrm{O}\right)$}
\end{tabular}

\subsection{ATR-FTIR}

The FTIR spectra of MK and residues analyzed are shown in Figure 4. As reported elsewhere [45,55,56], a broadened band is visible in the region of Si-O vibration (900-1200 $\mathrm{cm}^{-1}$ ), owing to amorphization of the crystalline kaolinite structure. Special attention will be paid to this band (zoomed region in Figure 4 from 850 to $1300 \mathrm{~cm}^{-1}$ ). As expected, $\mathrm{MK}$ and $\mathrm{MK}-\mathrm{H}_{2} \mathrm{O}$ behave similarly, and no differences can be found within the range of reproducibility of the measurements. With MK-MOH and MK-KOH, a slight shift in the band to smaller wave numbers and a broadening of the peak can be observed. $\mathrm{MK}-\mathrm{NaOH}$ leads to a clear shift in the band to smaller wave numbers. Table 8 summarizes the determined wave numbers and the corresponding full width at half maximum (FWHM). 


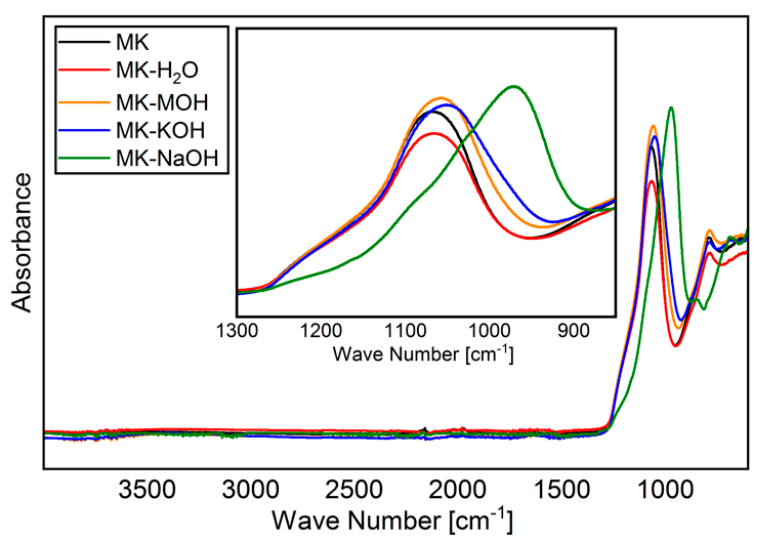

Figure 4. FTIR spectra of all samples analyzed.

Table 8. Summary of the determined wavenumbers and FWHM of the broadened Si-O band.

\begin{tabular}{ccc}
\hline Sample & Wavenumber $\left[\mathbf{c m}^{-\mathbf{1}}\right]$ & FWHM $\left[\mathbf{c m}^{-\mathbf{1}}\right]$ \\
\hline $\mathrm{MK}$ & $1068 \pm 3$ & $173 \pm 3$ \\
$\mathrm{MK}-\mathrm{H}_{2} \mathrm{O}$ & $1066 \pm 3$ & $178 \pm 3$ \\
$\mathrm{MK}-\mathrm{MOH}$ & $1058 \pm 3$ & $194 \pm 5$ \\
$\mathrm{MK}-\mathrm{KOH}$ & $1051 \pm 3$ & $198 \pm 5$ \\
$\mathrm{MK}-\mathrm{NaOH}$ & $982 \pm 10$ & $226 \pm 5$ \\
\hline
\end{tabular}

\subsection{SEM Images}

Figure 5 A-D display the SEM images of the gold coated samples. Owing to the similarity of $\mathrm{MK}-\mathrm{MOH}$ and $\mathrm{MK}-\mathrm{KOH}$, only $\mathrm{MK}-\mathrm{KOH}$ is shown. There are no optical differences visible between $\mathrm{MK}$ and $\mathrm{MK}-\mathrm{H}_{2} \mathrm{O}$. The treatment in distilled water has no effect on the shape, size and habitus of the metakaolin particles. Differences are also very small in comparison to $\mathrm{MK}-\mathrm{KOH}$. On closer inspection, a reduction in particle size caused by the dissolution process can be implied. Clear differences become obvious for $\mathrm{MK}-\mathrm{NaOH}$. Here, an alteration of the metakaolin particles takes place. The dissolution process has progressed so far that the mean particle size decreases and the morphology of many particles has changed significantly.
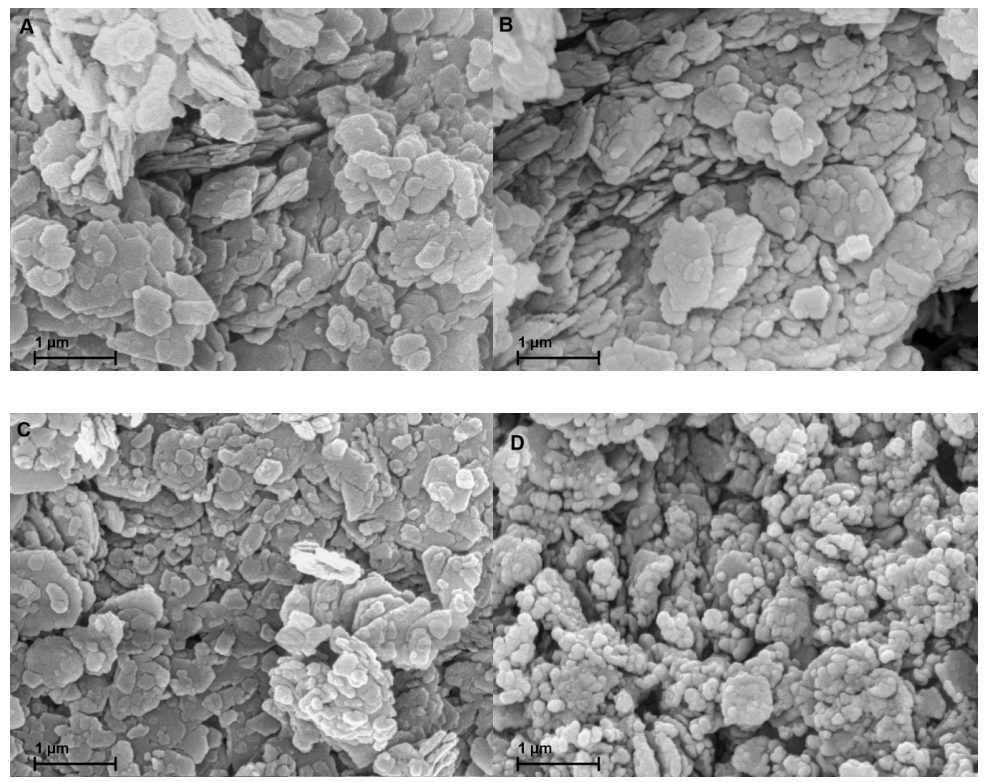

Figure 5. SEM images of the samples coated with gold of (A) $\mathrm{MK}$; (B) $\mathrm{MK}-\mathrm{H}_{2} \mathrm{O}$; (C) MK-KOH; (D) $\mathrm{MK}-\mathrm{NaOH}$. 


\subsection{Calculations of the Degree of Reaction}

Figure 6 displays the results of the calculations of the degree of reaction based on the weighing of the filter residue (Table 4), the QPXRD (Table 5) and the Si/Al-solubility (Table 6). The calculation of the degree of reaction of $R_{\text {weight }}$ (Equation (1), Section 2.6) considers the crystalline phases in comparison to the weighing of the filter residue (Table 4). The differences in mass are related exclusively to the X-ray amorphous fraction and thus reflect the mass loss in percent. Since errors in the quantification of one phase do not affect the quantification of another phase when calculating the phase contents following the G-factor method [48,57], the degree of reaction was determined from both the quantification of the quartz and of the $\mathrm{MK}_{\mathrm{Am}}$. An increase in the degree of reaction from MK-MOH via $\mathrm{MK}-\mathrm{KOH}$ to $\mathrm{MK}-\mathrm{NaOH}$ can be observed. In all systems, the degree of reaction calculated from the Si/Al-solubility is the highest, while the degrees of reaction calculated from XRD quantifications are the lowest. For the calculation of the degree of reaction from the results of the XRD quantifications ( $R_{\text {Quartz }}$ and $R_{M K A M}$ ) a large error in the degrees of reaction occurs. This effect is particularly pronounced with MK-MOH and $\mathrm{MK}-\mathrm{KOH}$ due to higher error propagation at lower reaction rates. Thus, for $\mathrm{MK}-\mathrm{NaOH}$ the error in the degree of reaction is significantly lower. This is in line with observations in the literature, which also find a large error in the degree of reaction calculated from XRD quantifications for low reaction rates or low SCM contents [26,36]. Another reason for the large errors in the degree of reaction calculated from the XRD quantifications results from the experimental setup, as the degree of reaction does not reflect the decrease in $\mathrm{MK}_{\mathrm{AM}}$ in the sample. A degree of reaction of $12.3 \%(\mathrm{MK}-\mathrm{MOH})$ only leads to a difference in $\mathrm{MK}_{\mathrm{AM}}$ of $0.9 \mathrm{wt} . \%$ and thus to large errors in the calculated degree of reaction based on XRD quantifications of $\mathrm{MK}_{\mathrm{AM}}$ with an accuracy of $\pm 1 \mathrm{wt}$.\%. Due to the strong error propagation from the XRD quantifications, the data obtained must be interpreted with caution. This is also known from the calculation of the degree of reaction with results of other test methods which exhibit small deviations of the determined contents. Scrivener et al. [58] report, for instance, a possible relative error of $\pm 50 \%$, when calculating the degree of reaction from the $\mathrm{CH}$ consumption determined by TG. The absolute differences in the degree of reaction $(\Delta R)$ increase with increasing degree of reaction, while the relative differences $\left(\Delta R / R_{\max }\right)$ decrease (Table 9$)$.

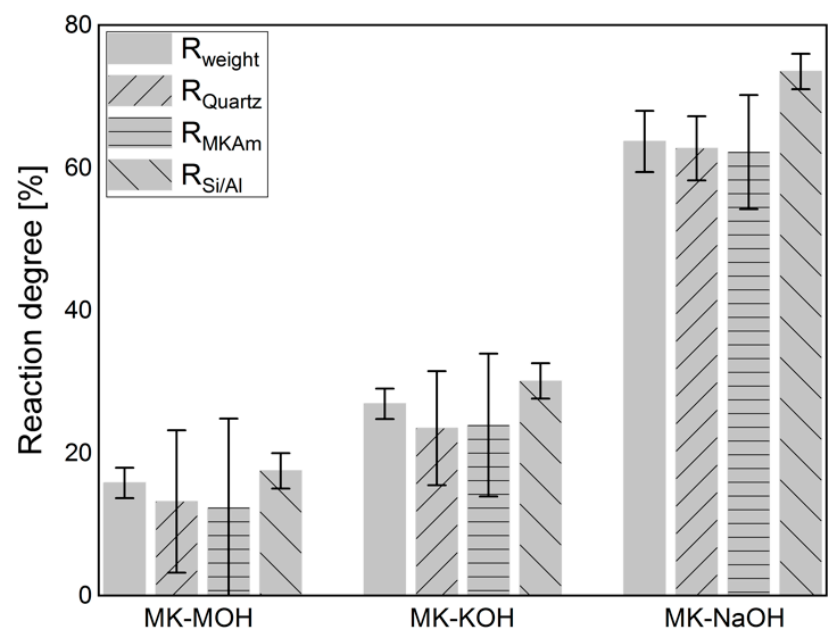

Figure 6. Degree of reaction calculated according to different approaches (Section 2.6).

Table 9. Summary of the minimal $\left(R_{\min }\right)$ and maximal $\left(R_{\max }\right)$ degree of reaction, their absolute difference $(\Delta R)$ and their relative difference $\left(\Delta R / R_{\max }\right)$.

\begin{tabular}{ccccc}
\hline & $\mathbf{R}_{\min }$ & $\mathbf{R}_{\max }$ & Absolute Difference $\boldsymbol{\Delta} \mathbf{R}[\%]$ & Relative Difference $\Delta \mathbf{R} / \mathbf{R}_{\max }[\%]$ \\
\hline MK-MOH & 12.3 & 17.5 & 5.2 & 30.0 \\
MK-KOH & 23.5 & 30.1 & 6.6 & 22.0 \\
MK-NaOH & 62.2 & 73.5 & 11.3 & 15.4 \\
\hline
\end{tabular}




\section{Discussion}

\subsection{Changes of $M K_{A m}$}

The dissolution of $\mathrm{MK}_{\mathrm{Am}}$ leads to a decrease in the X-ray amorphous hump (Figure 3) and thus a corresponding enrichment of the crystalline phases since these phases are not dissolved. A comparison of the scattering contribution of the X-ray amorphous hump between $\mathrm{MK}-\mathrm{NaOH}$ and a MK sample mixed with $10 \mathrm{wt} . \% \mathrm{ZnO}$ as internal standard $\left(\mathrm{MK}-10 \mathrm{ZnO} ; \mathrm{MK}_{\mathrm{Am}}=83.7 \mathrm{wt} . \%\right)$ confirms this observation. There is only a small difference in the diffractogram between $\mathrm{MK}-10 \mathrm{ZnO}$ and $\mathrm{MK}-\mathrm{NaOH}$ in the area from $15^{\circ}-30^{\circ} 2 \Theta$, where the scattering contribution of metakaolin is visible (Figure 7). Thus, the quantification of $\mathrm{MK}-\mathrm{NaOH}$ is reliable since the result (83.4 wt.\%) corresponds with the $\mathrm{MK}_{\mathrm{Am}}$ content of MK-10ZnO. Other effects, like, for instance, geopolymerization, can be ruled out. According to Williams [59] geopolymerization would result in a clear shift in the X-ray amorphous hump. No such effect and thus no geopolymer formation can be detected from the XRD data. Additional thermogravimetric analyses show only a small mass loss ( $<1 \mathrm{wt}$. $\%)$ for all samples. Thus, the high water to solid ratio of 80 is sufficient to avoid condensation of geopolymers. The studies of Kaps et al. [11,60] confirm this. According to Palomo, et al. [61], geopolymers are formed in several stages. The contact of aluminosilicates with high $\mathrm{pH}$ solutions leads to the dissolution of Si- and Almonomers, which in turn interact and form dimers, trimers and so on. If a saturation point is exceeded, geopolymers condense. This saturation point is not reached with the selected high water to solids ratio [33].

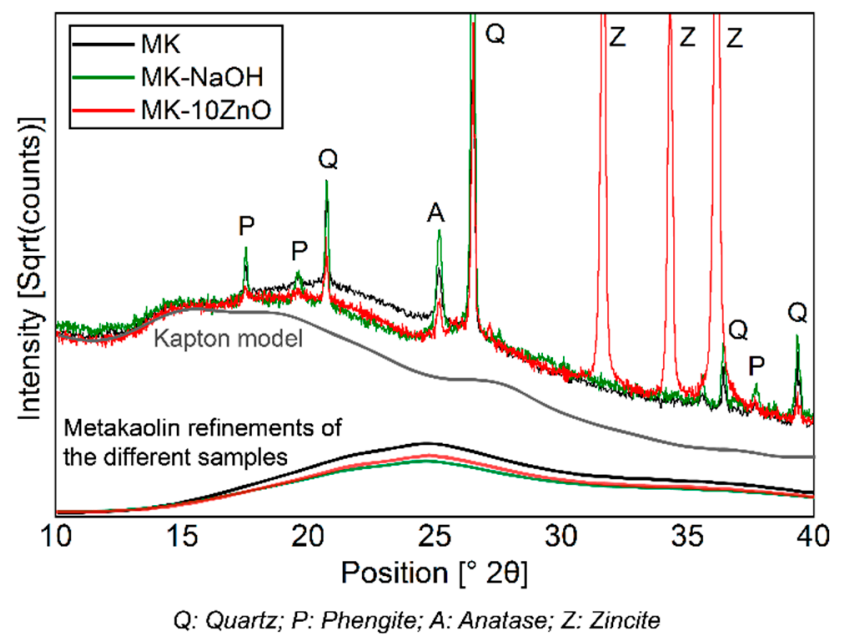

Figure 7. Comparison of diffractograms of $\mathrm{MK}-\mathrm{NaOH}$ and a $\mathrm{MK}$ sample mixed with $10 \mathrm{wt}$.\% $\mathrm{ZnO}$ as internal standard. The scattering contribution to the diffractogram of $\mathrm{MK}_{\mathrm{Am}}$ of the different samples and of the Kapton model is shown.

Based on the results of $\mathrm{R}_{\mathrm{Si} / \mathrm{Al}}$ of $\mathrm{MK}-\mathrm{NaOH}$ given in Figure 6, the $\mathrm{MK}_{\mathrm{Am}}$ content in the residue should be $78 \mathrm{wt} . \%$. Here, the uptake of alkalis seems to have a direct influence on the diffractogram, namely increasing the scattering contribution of metakaolin compared to the dissolved Si- and Almonomers. Pore solution tests on cement paste [62-66] in cementitious systems yield, in comparison, a significantly reduced availability of alkalis $(\mathrm{c}(\mathrm{Na}) \approx 50 \mathrm{mmol} / \mathrm{L}, \mathrm{c}(\mathrm{K}) \approx 450 \mathrm{mmol} / \mathrm{L}$ [64]), and thus the effect should be reduced on the diffractogram which is caused by alkali uptake. As a result, the quantification of metakaolin in cementitious systems is influenced only to a minor extent by alkali uptake. Quantifications of the degree of reaction of metakaolin in cementitious systems with the PONKCS method [28] also confirm this assumption. An accurate modelling and calibration of the X-ray amorphous content as well as a precise description of the background [38] seems to be more important for a reliable quantification with the PONKCS method. 
The analysis of the FTIR data reveals a significant structural change in the $\mathrm{MK}_{\mathrm{Am}}$. A shift in the position of the Si-O band maximum as well as a broadening of the peak can be observed. The related literature $[45,67]$ reports a shift in this band to smaller wave numbers depending on the silicon content in the aluminosilicate structure. The dependence of the wave number (Table 8) on the silicon content (Table 7) is elaborated in Figure 8a. There is a good correlation between the silicon content and the shift in the band. A similar correlation is given for the molar ration of $\mathrm{SiO}_{2} /\left(\mathrm{Al}_{2} \mathrm{O}_{3}+\mathrm{Fe}_{2} \mathrm{O}_{3}+\mathrm{TiO}_{2}+\mathrm{Na}_{2} \mathrm{O}\right.$ $+\mathrm{K}_{2} \mathrm{O}$ ) (Figure 8b). The enrichment of $\mathrm{Fe}_{2} \mathrm{O}_{3}$ and $\mathrm{TiO}_{2}$, as well as the uptake of alkalis, might influence the chemical environment of the $\mathrm{Si}-\mathrm{O}$ band. A possible increase in the bond length of the Si-O band might induce the shift to lower wavenumbers. The FWHM can indicate the degree of disorder within a structure. Disordered structures show a broader peak than ordered structures $[45,68]$. Since parts of the kaolinite structure remain intact during calcination and transformation into metakaolin [39], the broadening of the peak can be interpreted as additional defects in the X-ray amorphous structure after treatment in alkaline solution according to Król et al. [45]. This effect can also be observed here. It is assumed that the ionic radii in 6-fold coordination with oxygen of $\mathrm{Na}^{+}(116 \mathrm{pm})$ and $\mathrm{K}^{+}(152 \mathrm{pm})$, which are significantly larger than $\mathrm{Si}^{4+}(54 \mathrm{pm})$ and $\mathrm{Al}^{3+}$ (53 pm) [69], also affect and additionally disorder the structure of the metakaolin. This highlights the correlation of $\mathrm{SiO}_{2} /\left(\mathrm{Al}_{2} \mathrm{O}_{3}+\right.$ $\mathrm{Fe}_{2} \mathrm{O}_{3}+\mathrm{TiO}_{2}+\mathrm{Na}_{2} \mathrm{O}+\mathrm{K}_{2} \mathrm{O}$ ) with the FWHM (Figure 8b). The $\mathrm{SiO}_{2}$ content shows a just as good correlation with the FWHM (Figure 8a). However, it is assumed that the broadening of the peak is less due to the $\mathrm{SiO}_{2}$ content than the enrichment of $\mathrm{Fe}_{2} \mathrm{O}_{3}$ and $\mathrm{TiO}_{2}$, as well as the uptake of alkalis. Garg and Skibsted [43] showed by NMR measurements before and after dissolution in alkaline solution that 5-fold coordinated Al dissolves preferably and conclude a higher structural stability for 4-fold coordinated Al. These modifications have an influence on the binding conditions of the metakaolin structure and thus could influence the position of the FTIR bands.

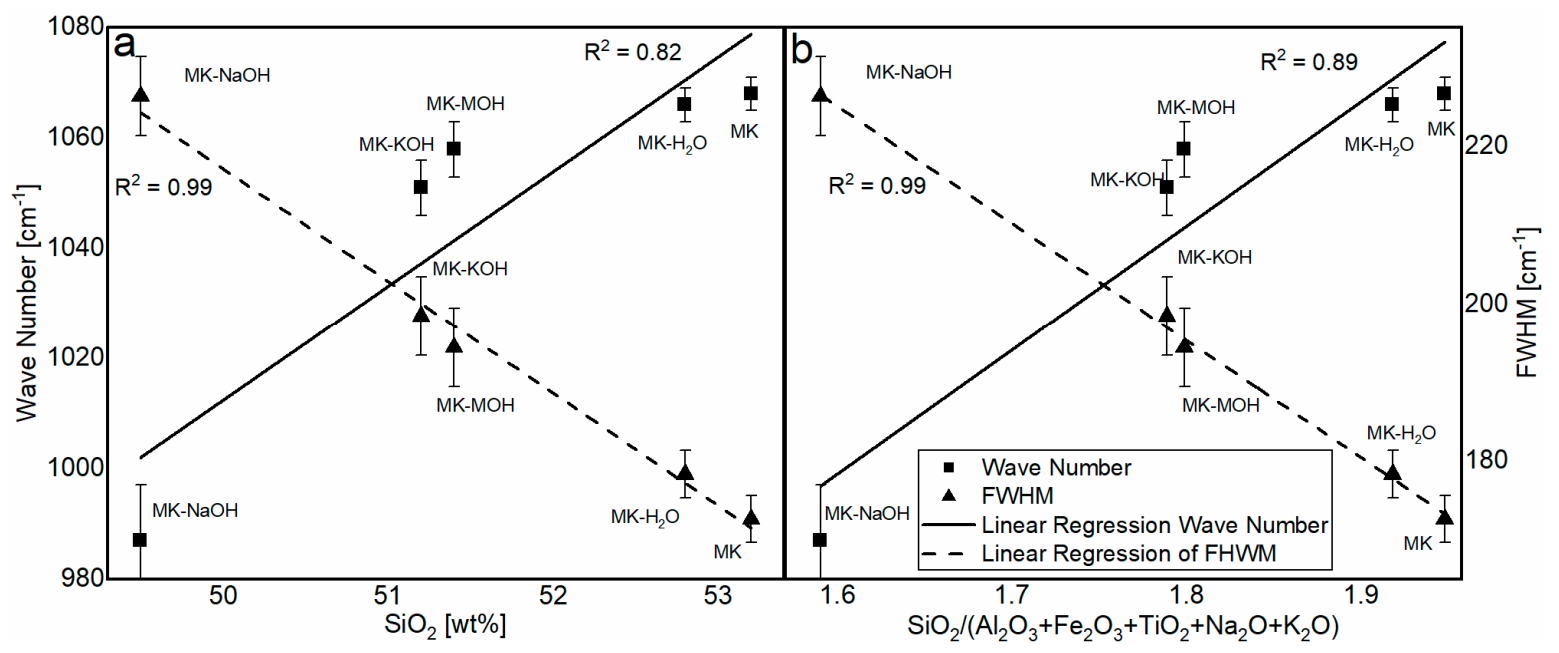

Figure 8. Correlation of the $\mathrm{SiO}_{2}$ content (a) and the molar ratio of $\mathrm{SiO}_{2} /\left(\mathrm{Al}_{2} \mathrm{O}_{3}+\mathrm{Fe}_{2} \mathrm{O}_{3}+\mathrm{TiO}_{2}+\mathrm{Na}_{2} \mathrm{O}\right.$ $\left.+\mathrm{K}_{2} \mathrm{O}\right)(\mathbf{b})$ in the aluminosilicate structure with the wavenumber and FWHM.

SEM investigations demonstrate the influence of the dissolution of the $\mathrm{Si}$ - and $\mathrm{Al}$-monomers on the shape of the particles. A dissolution process of the particles seems to take place. The enrichment of iron and titanium allows the conclusion that areas enriched with iron and titanium (Table 7) are hardly or not at all dissolved. As a result, metakaolin particles are not evenly dissolved from their edges and the SEM image of MK-NaOH (Figure 5D) could suggest the disintegration of the particles. Further investigations of the metakaolin particles in a transmission electron microscope could provide information about the element distribution within the particles. Inhomogeneous distribution of cations in the metakaolin structure could support the mentioned hypothesis.

Overall, the contribution of metakaolin to the pozzolanic reaction seems to be a congruent dissolution process. The almost constant $\mathrm{SiO}_{2} / \mathrm{Al}_{2} \mathrm{O}_{3}$ molar-ratio of about 2 (Table 7) in all investigated 
samples confirms that all areas are dissolved congruently and that neither Si- nor Al-ions are preferred. Thus, the structural changes seem to only slightly modify the scattering contribution of metakaolin to the diffractogram and the dissolution of metakaolin in alkaline solution, respectively, in cementitious systems is reflected in the decreasing X-ray amorphous hump in the diffractogram. In case of congruent dissolution, the same hkl-phase model of metakaolin can be used for quantification before and after treatment in alkaline solutions and thus enables a reliable quantification during cement hydration. Snellings [70] describes a shift in the X-ray amorphous hump towards lower angles $2 \Theta$ depending on the $\mathrm{SiO}_{2}$ content of synthesized calcium aluminosilicate glasses. In case of an incongruent dissolution process of metakaolin calcined at higher temperatures $\left(>900^{\circ} \mathrm{C}\right)$ [43], an enrichment of or reduction in the $\mathrm{SiO}_{2}$ content could also cause a shift in the X-ray amorphous hump. Such behavior could not be quantified with one hkl-phase model for metakaolin and would require the use of different hkl-phase models. As already described in the literature $[26,28,36,37,58]$, the PONKCS method offers a powerful opportunity to investigate the influence of X-ray amorphous SCM on the hydration of cements.

\subsection{Differences of the Degree of Reactions}

The comparison in Figure 6 of $R_{\text {weight }}$ and $R_{S i / A l}$ shows a lower degree of reaction for $R_{\text {weight }}$. The difference is due to the uptake of alkalis in $\mathrm{MK}_{\mathrm{Am}}$. The additional alkalis lead to a higher weight of the filter residue than calculated from the Si/Al-solubility only, and thus to a lower degree of reaction based on $\mathrm{R}_{\text {weight }}$ in comparison to $\mathrm{R}_{\mathrm{Si} / \mathrm{Al}}$. Consequently, the deviations between the two degrees of reaction increases with increasing alkali uptake. This relationship is illustrated in Figure 9. $\mathrm{MK}-\mathrm{H}_{2} \mathrm{O}$ is somewhat out of the range, because, on the one hand, the degree of reactions and thus the measurable effects are very low and, on the other hand, no alkalis are available for uptake in the distilled water. Without $\mathrm{MK}-\mathrm{H}_{2} \mathrm{O}$, the correlation fits very well and confirms the aforementioned.

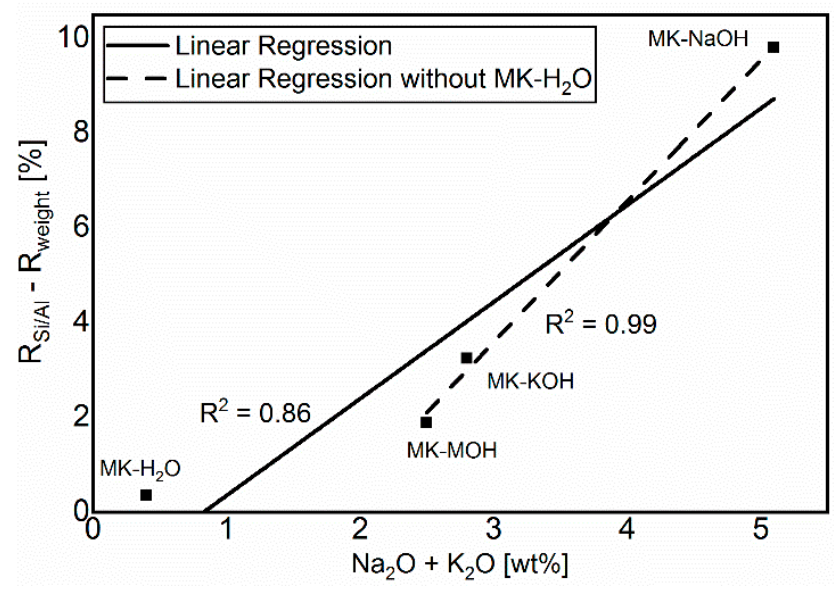

Figure 9. Correlation between the sum of alkalis and the difference of the calculated degrees of reaction.

When comparing the degrees of reaction within an alkaline solution, it is noticeable that $R_{\mathrm{Si} / \mathrm{Al}}$ is the highest for all investigated systems. From the evaluation of the weight of the filter residue and the QPXRD data, their lower calculated degree of reaction seems to be connected. Both the additional weight and the increased scattering contribution in the diffractogram appear to be related to the uptake of alkalis. This relationship is particularly evident for $\mathrm{MK}-\mathrm{NaOH}$. There is only a very small deviation in the calculated degrees of reaction between $R_{\text {weight }}$ and $R_{\text {Quartz }}$ or $R_{M K A m}$ (Figure 6).

More obvious differences exist between $R_{\text {weight }}$ and $R_{M K A m}$ or $R_{\text {Quartz }}$ for lower reaction degrees such as for MK-MOH and MK-KOH. A reason for this is the small quantitative difference in the $\mathrm{MK}_{\mathrm{Am}}$ content between the initial sample and the samples $\mathrm{MK}-\mathrm{MOH}$ and $\mathrm{MK}-\mathrm{KOH}$ after the test. Even small deviations in the quantification of the $\mathrm{MK}_{\mathrm{Am}}$ or quartz content ( \pm 1 or $\pm 0.5 \mathrm{wt} . \%$, Table 5) lead to significant errors in the calculation of the degree of reaction due to the experimental setup and error propagation (Figure 6). Avet, Li and Scrivener [26] and Snellings, Salze and Scrivener [36] showed in 
their investigations in cementitious systems that errors in the determination of the reacted metakaolin with the PONKCS method could lead to pronounced errors in the determination of the degree of reaction. This effect was also reported for other SCM like fly ash and slag [23]. Due to the resulting large errors, the data must be interpreted with care. Overall, the resulting trends appear to be consistent. The present investigations are not dealing with a hydrating system, but the XRD quantifications are performed before and after a dissolution process of metakaolin in alkaline solution. In contrast to Avet et al. [26], the results of the degree of reaction cannot be determined directly from the decrease of $\mathrm{MK}_{\mathrm{AM}}$. Thus, the results represent a comparison between the degree of reaction from the Si- and Al-solubility and the PONKCS quantifications, but the procedure cannot be transferred to hydrating systems. Nevertheless, these comparisons are important to evaluate and confirm the reliability of the PONKCS quantifications in reacting systems, as the reaction of metakaolin in hydrating systems is also a dissolution process.

The degrees of reaction in highly alkaline solutions determined here do not allow straightforward conclusions to be drawn about the degree of reaction of the SCM in cementitious systems. But the significantly higher solubility of $\mathrm{Si}$ and $\mathrm{Al}$ for $\mathrm{MK}-\mathrm{NaOH}$ in contrast to MK-KOH leads to the assumption that a higher degree of reaction of metakaolin may be expected in cements with a high sodium content in the pore solution. However, a classification of the reactivity of clays due to Si and Al solubility in $\mathrm{NaOH}$ solution with different metakaolin content [12] as well as of calcined clays and different phyllosilicates, seems possible and plausible [43,44,71]. This is in line with Maier, et al. [72], who found that $\mathrm{Si}$ - and Al-solubility, such as heat of hydration determined by $\mathrm{R}^{3}$ reactivity test [17], exhibit both comparable correlation with the total $\mathrm{Al}_{2} \mathrm{O}_{3}$ content as well as the kaolinite content of the clays.

\section{Conclusions}

The correlation of dissolved silicon and aluminum from dissolution experiments with XRD quantification on MK after treatment in alkaline solutions offers new insights into the possibilities and limitations of quantifying MK during pozzolanic reaction with the PONKCS method. After systematic investigations of the filtrate and the filter residue, the following conclusions can be drawn.

A change in the binding condition of metakaolin owing to the treatment in alkali solutions can be proven using ATR-FTIR. The enrichment of iron and titanium as well as the uptake of alkalis in the metakaolin structure seem to cause a shift in the $\mathrm{Si}-\mathrm{O}$ band to smaller wave numbers and a broadening of the bands.

The participation of the metakaolin in the pozzolanic reaction is a congruent dissolution process of the Si- and Al-monomers to a large extent. There seems to be an inhomogeneous distribution of the cations in the particles. Iron- and titanium-rich areas in the particles do not seem to dissolve and thus cause the particles to disintegrate.

These observations affect the intensity of the scattering contribution of the $\mathrm{MK}_{\mathrm{Am}}$ in the diffractogram. However, these structural changes do not cause any change in the position of the X-ray amorphous hump if the dissolution of the metakaolin particles is congruent. Therefore, it is reasonable to use one hkl-phase model for the quantification of metakaolin calcined at its optimum temperature between 500 and $800{ }^{\circ} \mathrm{C}$ before and after dissolution in alkaline solution as well as during the hydration of cementitious systems.

The effect of the uptake of alkalis on the intensity of the X-ray amorphous hump results in a difference in XRD quantifications compared to the expected value calculated from the dissolved Siand Al-ions. This effect can be measured for highly alkaline solutions on a pure metakaolin sample and leads to differences in the calculation of the degree of reaction. For common substitution rates of metakaolin in cementitious systems, where the content of alkalis in the pore solution is rather low, the effect on the quantification of $\mathrm{MK}_{\mathrm{Am}}$ with the PONKCS method seems to be negligible or at least below the error of the quantification. Accurate modelling and calibration, as well as a very precise description of the background, is more decisive for the success of the quantification. Consequently, the PONKCS method is a suitable method for investigating the quantity and reaction mechanisms of the X-ray 
amorphous SCMs involved in the hydration of cements. The strong effect of error propagation for low degrees of reaction and low substitution rates in cementitious systems remains a problem when calculating the degree of reaction based on quantifications using the PONKCS method.

Supplementary Materials: The following are available online at http://www.mdpi.com/1996-1944/13/10/2214/s1, Table S1: Chemical composition [wt.\%] of $\mathrm{MK}_{\mathrm{Am}}$ left after dissolution with different solvents of all samples measured with EDX and the molar ratio of $\mathrm{SiO}_{2} / \mathrm{Al}_{2} \mathrm{O}_{3}$ and $\mathrm{SiO}_{2} /\left(\mathrm{Al}_{2} \mathrm{O}_{3}+\mathrm{Fe}_{2} \mathrm{O}_{3}+\mathrm{TiO}_{2}+\mathrm{Na}_{2} \mathrm{O}+\mathrm{K}_{2} \mathrm{O}\right)$.

Author Contributions: Conceptualization, S.S., N.B. and K.-C.T.; methodology, S.S.; validation, S.S. and M.K.; investigation, S.S. and M.K.; data curation, S.S. and M.K.; writing-original draft preparation, S.S.; writing-review and editing, S.S., N.B., K.-C.T. and J.N.; supervision, K.-C.T. and J.N. All authors have read and agreed to the published version of the manuscript.

Funding: This research received no external funding.

Conflicts of Interest: The authors declare no conflict of interest.

\section{References}

1. Ramezanianpour, A.M.; Hooton, R.D. A study on hydration, compressive strength, and porosity of Portland-limestone cement mixes containing SCMs. Cem. Concr. Compos. 2014, 51, 1-13. [CrossRef]

2. Justnes, H. How SCMs Improve Concrete Durability-A Fundamental View. In Proceedings of the Fourth International Conference on Sustainable Construction Materials and Technologies, Las Vegas, NV, USA, 7-11 August 2016.

3. Sabir, B.B.; Wild, S.; Bai, J. Metakaolin and calcined clays as pozzolans for concrete: A review. Cem. Concr. Compos. 2001, 23, 441-454. [CrossRef]

4. Wang, A.; Kovler, K.; Provis, J.L.; Buchwald, A.; Cyr, M.; Patapy, C.; Kamali-Bernard, S.; Courard, L.; Sideris, K. Metakaolin. In Properties of Fresh and Hardened Concrete Containing Supplementary Cementitious Materials; De Belie, N., Soutsos, M., Gruyaert, E., Eds.; Springer International Publishing: Cham, Germany, 2018; pp. 153-179. [CrossRef]

5. Kadri, E.-H.; Kenai, S.; Ezziane, K.; Siddique, R.; De Schutter, G. Influence of metakaolin and silica fume on the heat of hydration and compressive strength development of mortar. Appl. Clay Sci. 2011, 53, 704-708. [CrossRef]

6. Said-Mansour, M.; Kadri, E.-H.; Kenai, S.; Ghrici, M.; Bennaceur, R. Influence of calcined kaolin on mortar properties. Constr. Build. Mater. 2011, 25, 2275-2282. [CrossRef]

7. Lothenbach, B.; Scrivener, K.; Hooton, R.D. Supplementary cementitious materials. Cem. Concr. Res 2011, 41, 1244-1256. [CrossRef]

8. Kadri, E.H.; Aggoun, S.; De Schutter, G.; Ezziane, K. Combined effect of chemical nature and fineness of mineral powders on Portland cement hydration. Mater. Struct. 2010, 43, 665-673. [CrossRef]

9. Raask, E.; Bhaskar, M.C. Pozzolanic activity of pulverized fuel ash. Cem. Concr. Res. 1975, 5, 363-375. [CrossRef]

10. Surana, M.S.; Joshi, S.N. Spectrophotometric method for estimating the reactivity of pozzolanic materials. Adv. Cem. Res. 1998, 1, 238-242. [CrossRef]

11. Kaps, C.; Buchwald, A. Property controlling influences on the generation of geopolymeric binders based on clay. In Proceedings of the Geopolymer 2002 3rd International Conference, Melbourne, Australia, 28-29 October 2002.

12. Buchwald, A.; Kriegel, R.; Kaps, C.; Zellmann, H.-D. Untersuchung zur Reaktivität von Metakaolinen für die Verwendung in Bindemittelsystemen. In Proceedings of the Gesellschaft Deutscher Chemiker e.V -Jahrestagung, Munich, Germany, 9-10 October 2003.

13. Katyal, N.K.; Sharma, J.M.; Dhawan, A.K.; Ali, M.M.; Mohan, K. Development of rapid method for the estimation of reactive silica in fly ash. Cem. Concr. Res 2008, 38, 104-106. [CrossRef]

14. Donatello, S.; Tyrer, M.; Cheeseman, C.R. Comparison of test methods to assess pozzolanic activity. Cem. Concr. Compos. 2010, 32, 121-127. [CrossRef]

15. Ferraz, E.; Andrejkovičová, S.; Hajjaji, W.; Velosa, A.L.; Silva, A.S.; Rocha, F. Pozzolanic Activity of Metakaolins by the French Standard of the Modified Chapelle Test: A Direct Methodology. Acta Geodyn. Geomater. 2015, 12, 289-298. [CrossRef] 
16. Quarcioni, V.A.; Chotoli, F.F.; Coelho, A.C.V.; Cincotto, M.A. Indirect and direct Chapelle's methods for the determination of lime consumption in pozzolanic materials. Rev. Ibracon Estrut. Mater. 2015, 8, 1-7. [CrossRef]

17. Avet, F.; Snellings, R.; Alujas Diaz, A.; Ben Haha, M.; Scrivener, K. Development of a new rapid, relevant and reliable $\left(\mathrm{R}^{3}\right)$ test method to evaluate the pozzolanic reactivity of calcined kaolinitic clays. Cem. Concr. Res. 2016, 85, 1-11. [CrossRef]

18. Li, X.; Snellings, R.; Antoni, M.; Alderete, N.M.; Ben Haha, M.; Bishnoi, S.; Cizer, Ö.; Cyr, M.; De Weerdt, K.; Dhandapani, Y.; et al. Reactivity tests for supplementary cementitious materials: RILEM TC 267-TRM phase 1. Mater. Struct. 2018, 51, 151. [CrossRef]

19. Tashiro, C.; Ikeda, K.; Inoue, Y. Evaluation of pozzolanic activity by the electric resistance measurement method. Cem. Concr. Res 1994, 24, 1133-1139. [CrossRef]

20. Roszczynialski, W. Determination of pozzolanic activity of materials by thermal analysis. J. Anal. Calorim. 2002, 70, 387-392. [CrossRef]

21. Baert, G.; Hoste, S.; De Schutter, G.; De Belie, N. Reactivity of fly ash in cement paste studied by means of thermogravimetry and isothermal calorimetry. J. Anal. Calorim. 2008, 94, 485-492. [CrossRef]

22. Ben Haha, M.; De Weerdt, K.; Lothenbach, B. Quantification of the degree of reaction of fly ash. Cem. Concr. Res. 2010, 40, 1620-1629. [CrossRef]

23. Durdziński, P.T.; Ben Haha, M.; Bernal, S.A.; De Belie, N.; Gruyaert, E.; Lothenbach, B.; Menéndez Méndez, E.; Provis, J.L.; Schöler, A.; Stabler, C.; et al. Outcomes of the RILEM round robin on degree of reaction of slag and fly ash in blended cements. Mater. Struct. 2017, 50, 135. [CrossRef]

24. Bhagath Singh, G.V.P.; Subramaniam, K.V.L. Method for Direct Determination of Glassy Phase Dissolution in Hydrating Fly Ash-Cement System Using X-ray Diffraction. J. Am. Ceram. Soc. 2017, 100, 403-412. [CrossRef]

25. Villagrán-Zaccardi, Y.A.; Vollpracht, A.; Gruyaert, E.; De Belie, N. Recommendation of RILEM TC 238-SCM: Determination of the degree of reaction of siliceous fly ash and slag in hydrated cement paste by the selective dissolution method. Mater. Struct. 2018, 51, 27. [CrossRef]

26. Avet, F.; Li, X.; Scrivener, K. Determination of the amount of reacted metakaolin in calcined clay blends. Cem. Concr. Res. 2018, 106, 40-48. [CrossRef]

27. Ramanathan, S.; Moon, H.; Croly, M.; Chung, C.-W.; Suraneni, P. Predicting the degree of reaction of supplementary cementitious materials in cementitious pastes using a pozzolanic test. Constr. Build. Mater. 2019, 204, 621-630. [CrossRef]

28. Naber, C.; Stegmeyer, S.; Jansen, D.; Goetz-Neunhoeffer, F.; Neubauer, J. The PONKCS method applied for time resolved XRD quantification of supplementary cementitious material reactivity in hydrating mixtures with ordinary Portland cement. Constr. Build. Mater. 2019, 214, 449-457. [CrossRef]

29. DIN EN 196-1. Prüfverfahren für Zement-Teil 1: Bestimmung der Festigkeit (Methods of Testing Cement-Part 1: Determination of Strength); Beuth-Verlag: Berlin, Germany, 2016; p. 31.

30. DIN EN 196-5. Prüfverfahren für Zement-Teil 5: Prüfung der Puzzolanität von Puzzolanzementen (Methods of Testing Cement_Part 5: Pozzolanicity Test for Pozzolanic Cement); Beuth-Verlag: Berlin, Germany, 2011; p. 14.

31. Chatterjee, A.K. Pozzolanicity of Calcined Clay. In 1st International Conference Calcined Clays for Sustainable Concrete; Scrivener, K., Favier, A., Eds.; Springer: Lausanne, The Netherlands, 2015; pp. 83-89. [CrossRef]

32. Antiohos, S.K.; Tsimas, S. Reactive Silica of Fly Ash as an Indicator for the Mechanical Performance of Blended Cements. In Measuring, Monitoring and Modeling Concrete Properties; Konsta-Gdoutos, M.S., Ed.; Springer: Dordrecht, The Netherlands, 2006; pp. 403-409. [CrossRef]

33. Snellings, R.; Scrivener, K.L. Rapid screening tests for supplementary cementitious materials: Past and future. Mater. Struct. 2016, 49, 3265-3279. [CrossRef]

34. Kalina, R.D.; Al-Shmaisani, S.; Ferron, R.D.; Juenger, M.C.G. False Positives in ASTM C618 Specifications for Natural Pozzolans. ACI Mater. J. 2019, 116, 165-172. [CrossRef]

35. Scarlett, N.V.Y.; Madsen, I.C. Quantification of phases with partial or no known crystal structures. Powder Diffr. 2006, 21, 278-284. [CrossRef]

36. Snellings, R.; Salze, A.; Scrivener, K.L. Use of X-ray diffraction to quantify amorphous supplementary cementitious materials in anhydrous and hydrated blended cements. Cem. Concr. Res. 2014, 64, 89-98. [CrossRef] 
37. Stetsko, Y.P.; Shanahan, N.; Deford, H.; Zayed, A. Quantification of supplementary cementitious content in blended Portland cement using an iterative Rietveld-PONKCS technique. J. Appl. Crystallogr. 2017, 50, 498-507. [CrossRef]

38. Scherb, S.; Beuntner, N.; Thienel, K.-C.; Neubauer, J. Quantitative X-ray diffraction of free, not chemically bound water with the PONKCS method. J. Appl. Crystallogr. 2018, 51, 1535-1543. [CrossRef]

39. Brindley, G.W.; Nakahira, M. The Kaolinite-Mullite Reaction Series: II, Metakaolin. J. Am. Ceram. Soc. 1959, 42,314-318. [CrossRef]

40. Massiot, D.; Dion, P.; Alcover, J.F.; Bergaya, F. 27Al and 29Si MAS NMR Study of Kaolinite Thermal Decomposition by Controlled Rate Thermal Analysis. J. Am. Ceram. Soc. 1995, 78, 2940-2944. [CrossRef]

41. Halse, Y.; Pratt, P.L.; Dalziel, J.A.; Gutteridge, W.A. Development of microstructure and other properties in flyash OPC systems. Cem. Concr. Res. 1984, 14, 491-498. [CrossRef]

42. Granizo, N.; Palomo, A.; Fernandez-Jiménez, A. Effect of temperature and alkaline concentration on metakaolin leaching kinetics. Ceram. Int. 2014, 40, 8975-8985. [CrossRef]

43. Garg, N.; Skibsted, J. Dissolution kinetics of calcined kaolinite and montmorillonite in alkaline conditions: Evidence for reactive Al(V) sites. J. Am. Ceram. Soc. 2019, 102, 7720-7734. [CrossRef]

44. Scherb, S.; Beuntner, N.; Thienel, K.-C. Reaction kinetics of the basic clays present in natural mixed clays. In Calcined Clays for Sustainable Concrete, Proceedings of the 2nd International Conference on Calcined Clays for Sustainable Concrete, La Havanna, Cuba, 5-7 December 2017; Springer: Dordrecht, The Netherlands, 2018; pp. 427-433.

45. Król, M.; Minkiewicz, J.; Mozgawa, W. IR spectroscopy studies of zeolites in geopolymeric materials derived from kaolinite. J. Mol. Struct. 2016, 1126, 200-206. [CrossRef]

46. Król, M.; Rożek, P.; Chlebda, D.; Mozgawa, W. ATR/FT-IR studies of zeolite formation during alkali-activation of metakaolin. Solid State Sci. 2019, 94, 114-119. [CrossRef]

47. O'Connor, B.H.; Raven, M.D. Application of the Rietveld refinement procedure in assaying powdered mixtures. Powder Diffr. 1988, 3, 2-6. [CrossRef]

48. Jansen, D.; Goetz-Neunhoeffer, F.; Stabler, C.; Neubauer, J. A remastered external standard method applied to the quantification of early OPC hydration. Cem. Concr. Res 2011, 41, 602-608. [CrossRef]

49. Bergold, S.T.; Goetz-Neunhoeffer, F.; Neubauer, J. Quantitative analysis of C-S-H in hydrating alite pastes by in-situ XRD. Cem. Concr. Res 2013, 53, 119-126. [CrossRef]

50. Le Page, Y.; Donnay, G. Refinement of the crystal structure of low-quartz. Acta Crystallogr. Sect. B Struct. Sci. 1976, 32, 2456-2459. [CrossRef]

51. Horn, M.; Schwerdtfeger, C.F.; Meagher, E.P. Refinement of the structure of anatase at several temperatures. Zeitschrift Für Kristallographie Cryst. Mater. 1972, 136, 273-281. [CrossRef]

52. Ivaldi, G.; Ferraris, G.; Curetti, N.; Compagnoni, R. Coexisting 3T and 2M1 polytypes of phengite from Cima Pal (Val Savenca, western Alps): Chemical and polytypic zoning and structural characterisation. Eur. J. Mineral. 2001, 13, 1025-1034. [CrossRef]

53. DIN EN ISO 11885. Water Quality-Determination of Selected Elements by Inductively Coupled Plasma Optical Emission Spectrometry (ICP-OES); Beuth-Verlag: Berlin, Germany, 2009 ; p. 37.

54. Licht, S. pH Measurement in Concentrated Alkaline Solutions. Anal. Chem. 1985, 57, 514-519. [CrossRef]

55. Chakchouk, A.; Trifi, L.; Samet, B.; Bouaziz, S. Formulation of blended cement: Effect of process variables on clay pozzolanic activity. Constr. Build. Mater. 2009, 23, 1365-1373. [CrossRef]

56. Tironi, A.; Trezza, M.A.; Irassar, E.F.; Scian, A.N. Thermal Treatment of Kaolin: Effect on the Pozzolanic Activity. Procedia Mater. Sci. 2012, 1, 343-350. [CrossRef]

57. Jansen, D.; Stabler, C.; Goetz-Neunhoeffer, F.; Dittrich, S.; Neubauer, J. Does Ordinary Portland Cement contain amorphous phase? A quantitative study using an external standard method. Powder Diffr. 2012, 26, 31-38. [CrossRef]

58. Scrivener, K.L.; Lothenbach, B.; De Belie, N.; Gruyaert, E.; Skibsted, J.; Snellings, R.; Vollpracht, A. TC 238-SCM: Hydration and microstructure of concrete with SCMs. Mater. Struct. 2015, 48, 835-862. [CrossRef]

59. Williams, R.P. Quantification of the Extent of Reaction of Metakaolin-Based Geopolymers Using X-Ray Diffraction, Scanning Electron Microscopy, and Energy-Dispersive Spectroscopy. J. Am. Ceram. Soc. 2011, 94, 2663-2670. [CrossRef] 
60. Kaps, C.; Buchwald, A.; Hohmann, M.; Zellmann, H.-D. Untersuchungen zur Binderoptimierung in alumosilikatischen Polymerbindern. In Proceedings of the 15 Internationale Baustofftagung Ibausil, Weimar, Germany, 24-27 September 2003.

61. Palomo, A.; Krivenko, P.; Garcia-Lodeiro, I.; Maltseva, O.; Fernández-Jiménez, A. A review on alkaline activation: New analytical perspectives. Mater. Constr. 2014, 64. [CrossRef]

62. Andersson, K.; Allard, B.; Bengtsson, M.; Magnusson, B. Chemical composition of cement pore solutions. Cem. Concr. Res. 1989, 19, 327-332. [CrossRef]

63. Caruso, F.; Mantellato, S.; Palacios, M.; Flatt, R.J. ICP-OES method for the characterization of cement pore solutions and their modification by polycarboxylate-based superplasticizers. Cem. Concr. Res. 2017, 91, 52-60. [CrossRef]

64. Vollpracht, A.; Lothenbach, B.; Snellings, R.; Haufe, J. The pore solution of blended cements: A review. Mater. Struct. 2016, 49, 3341-3367. [CrossRef]

65. Schöler, A.; Lothenbach, B.; Winnefeld, F.; Haha, M.B.; Zajac, M.; Ludwig, H.-M. Early hydration of SCM-blended Portland cements: A pore solution and isothermal calorimetry study. Cem. Concr. Res. 2017, 93, 71-82. [CrossRef]

66. Vollpracht, A.; Lothenbach, B.; Snellings, R.; Haufe, J. Influence of SCM on Pore Solution Composition. In Proceedings of the International RILEM Conference Materials Systems and Structures in Civil Engineering 2016 (MSSCE 2016), Lynby, Denmark, 22-24 August 2016; pp. 309-318.

67. Kosslick, H.; Fricke, R. Chemical Analysis of Aluminosilicates, Aluminophosphates and Related Molecular Sieves. In Characterization II; Karge, H.G., Weitkamp, J., Eds.; Springer: Berlin/Heidelberg, Germany, 2007; pp. 1-66. [CrossRef]

68. Król, M.; Mozgawa, W.; Morawska, J.; Pichór, W. Spectroscopic investigation of hydrothermally synthesized zeolites from expanded perlite. Microporous Mesoporous Mater. 2014, 196, 216-222. [CrossRef]

69. Shannon, R.D.; Prewitt, C.T. Effective ionic radii in oxides and fluorides. Acta Crystallogr. Sect. B 1969, 25, 925-946. [CrossRef]

70. Snellings, R. Solution-Controlled Dissolution of Supplementary Cementitious Material Glasses at pH 13: The Effect of Solution Composition on Glass Dissolution Rates. J. Am. Ceram. Soc. 2013, 96, 2467-2475. [CrossRef]

71. Beuntner, N.; Thienel, K.-C. Solubility and kinetics of calcined clay: Study of interaction by pore solution. In Proceedings of the 2nd International Conference on the Chemistry of Construction Materials (ICCCM 2016), Munich, Germany, 10-12 October 2016; pp. 157-160.

72. Maier, M.; Beuntner, N.; Thienel, K.-C. An approach for the evaluation of local raw material potential for calcined clay as SCM, based on geological and mineralogical data: Examples from German clay deposits. In Proceedings of the 3rd International Conference on Calcined Clays for Sustainable Concrete, Delhi, India, 15-17 October 2019.

(C) 2020 by the authors. Licensee MDPI, Basel, Switzerland. This article is an open access article distributed under the terms and conditions of the Creative Commons Attribution (CC BY) license (http://creativecommons.org/licenses/by/4.0/). 